\title{
Changes in Lizard Abundance on Protected Versus Grazed Desert Scrub in Baja California Sur, Mexico
}

\author{
Romero-Schmidt Heidi L*. and Alfredo Ortega-Rubio \\ Centro de Investigaciones Biologicas del Noroeste. Apartado Postal No 128, La Paz, 23000, Baja California \\ Sur, México
}

\begin{abstract}
The changes in abundance of three species of lizards were determined and compared between grazed and ungrazed desert scrub near La Paz, in the Cape Region, Baja California Sur, Mexico, from April 1992 to March 1993. A total of 54 censuses were taken of these species over two transect systems, one inside and one outside livestock enclosure. Urosaurus nigricaudus were negatively affected by the grazing activities, but Uta stansburiana exhibited an apparently positive effect by such activities. Cnemidophorus hyperythrus population apparently showed no effect by the livestock grazing. The paper discusses the possible relationship between the microhabitat specificity of each species and their population number individuals response.
\end{abstract}

Key words: Baja California Sur, Lizard abundance, Livestock grazing, Mexico.

\section{INTRODUCTION}

Domestic livestock grazing are common over the whole Cape Region, Baja California Sur, Mexico. Although many studies have investigated the influence of livestock grazing on vegetation elsewhere (Anderson \& Holte, 1981; Chew, 1982; West et al., 1984; Milchunas et al, 1988), few have investigated the impact of livestock grazing on the fauna such as reptiles (Janzen, 1976; Bock et al., 1984, 1990; Romero-Schmidt et al., 1994); rodent and lagomorphs (Linsdale, 1946; Reynolds, 1950); and invertebrates (Heske \& Campbell, 1991).

Several authors have found that lizard population numbers were inversely related with grazing intensity (Bury \& Busack, 1974; Jones, 1981). However, most of the work has been done at other desert and semidesert habitats from North America, but no previous work has been done on such effects in the Baja California peninsula.

The objective of this study was to examine how vegetative changes, associated with grazing, affected lizard species population numbers. Because lizards are both predators and prey, they play a multifaceted role in community structure and function. Consequently, an understanding of the impact grazing on peninsular semidesert habitats and the associated lizard fauna is of practical value.

\section{MATERIAL AND METHODS}

The study was conducted in a 215 ha area, owned by the Center of Biological Research of the Northwest (CIBNOR) at "El Comitan" in the northern part of the Cape Region in the state of Baja California Sur, Mexico. "El Comitan" is 17 km north of La Paz (24 $10^{\prime} \mathrm{N}$; $110^{\circ} 30^{\prime} \mathrm{W}$ ), and it is a coastal lowland (10 above sea level) with mud-sandy soils (Alvarez et al., 1989). Its predominant flora is xerophytic scrub (Leon De La Luz et al., 1998) and is composed mainly of the following cacti: Pachycereus pringlei (Cardón), Stenocereus gummosus (pitaya dulce), and Stenocereus thurberii (pitaya agria); trees: Prosopis articulata (mesquite) and Bursera microphylla (torote), and shrubs: Jatropha cinerea (lomboy) and Fouqueria diguetti (palo adán) (Alvarez et al., 1989). The weather of the zone is $B W\left(h^{\prime}\right)$ hw $\left(x^{\prime}\right)(e)$ (García, 1973). It is an arid climate with the average annual temperature of $23.9^{\circ} \mathrm{C}$, with a mean annual

\footnotetext{
* Author for correspondence
} 
precipitation of $62 \mathrm{~mm}$, concentrated mostly during the summer (August and September).

Livestock have been excluded from the CIBNOR property for about seven years. For the present study, we established a 2,500 $\mathrm{m}^{2}$ transect system inside the enclosure (Site 1). In this system, we established ten, $50 \mathrm{~m}$ long transects, $10 \mathrm{~m}$ apart and marked by flagged wire stakes at 5 meter intervals. Outside the enclosure, in a grazed boundary ranch, we established an identical system of transects (Site 2).

Lizard abundance was estimated over a year period by counting the number of lizards observed per given time spent steadily looking for them. Lizards were detected by their movements. Censuses were done during 50 minutes searches in each transect system two days each month. For each lizard observed, the date, time, species, and specific position inside the transect were recorded. Each census started from a different location inside the transect system to try to avoid differences obtained by the lizard activities associated to the time of the day.

To determine vegetation structure and microhabitat characteristics the following variables were recorded in a $1 \mathrm{~m}^{2}$ area around each flagged wire stake: average height and cover of grasses, cacti, shrubs and trees (Moore \& Chapman, 1986); Plant species richness and density (Moore \& Chapman, 1986), and percent of rock, fallen tree trunks and bare soil cover, were visually estimated (Ortega et al., 1989).

\section{RESULTS}

The lizard community was composed eleven species (Alvarez et al., 1989). The most abundant lizards on the study plot were: Urosaurus nigricaudus, Cnemidophorus hyperythrus and Uta stansburiana. Other lizards present were Phrynosoma coronatum, Dipsosaurus dorsalis, Callisaurus draconoides, Sceloporus monserratensis, S. zosteromus, Ctenosaura hemilopha, Coleonyx variegatus and Phyllodactylus unctus.
Individual lizards belonging to the most abundant species were seen mainly in the following microhabitats: Urosaurus nigricaudus (a Cape Region endemic species) on trees and small or medium rocks; Cnemidophorus hyperythrus hyperythrus (a Cape Region endemic subspecies) on the ground. Uta stansburiana on fallen tree trunks, large rocks, and rock walls.

Table 1 shows the monthly abundance data for the lizards studied. For $U$. nigricaudus and $U$. stansburiana, both inside and outside the enclosure, the maximum abundance was during June. For both species, there was an abrupt decline from June to July, with further gradual decline until December. This was also true for $C$. hyperythrus inside the enclosure with the abundance peak in June. For the three species, both inside and outside the enclosure, there was no activity from December to February.

Table 2 shows the average abundance, both inside and outside the enclosure. There were differences in lizard abundances between both sites. Two significative differences were those related to the greater abundance of Urosaurus nigricaudus outside the enclosure $(\mathrm{t}=2.260 ; \mathrm{p}<$ $0.01)$, and Uta stansburiana inside $(\mathrm{t}=4.141 ; \mathrm{p}$ $<0.001)$. For Cnemidophorus hyperythrus there were no significant differences in either area $(t=$ $1.520 ; \mathrm{p}>0.05)$.

Table 3 shows the microhabitat characteristics at both the sites. There were remarkable differences in substrate availability related to grass and herb cover $\left(X^{2}=53.06 ; \mathrm{p}<0.001\right)$ and average height $\left(X^{2}=16.33 ; \mathrm{p}<0.001\right)$, which was higher inside the enclosure, and those related to the proportion of exposed soil cover $\left(X^{2}=1008.20 ; \mathrm{p}<0.001\right)$ and fallen tree trunks $\left(X^{2}=3.98 ; \mathrm{p}<0.05\right)$, which were significantly higher outside the enclosure.

For all the trees, shrubs, and cactus characteristics considered (Table 3), only a few related to the structure, density, and diversity of the perennial vegetation showed significant differences between outside and inside. These were: tree density (higher inside), shrub density (higher outside), and percent of cactus species (higher outside). 
Table 1. Standardized data average (number of lizard individuals, found during each census, multiplied by 100) of the individuals found monthly in the transects. Inside $(\mathrm{I})$ and Outside $(\mathrm{O})$ of the livestock enclosure area.

\begin{tabular}{|c|c|c|c|c|c|c|}
\hline Month & Area & No. Census & Urosaurus & Uta & Cnemidophorus & Total \\
\hline \multirow[t]{2}{*}{ April } & $\mathrm{O}$ & 3 & 66.6 & 66.6 & 100 & 233.3 \\
\hline & I & 3 & 33.3 & 133.3 & 200 & 366.6 \\
\hline \multirow[t]{2}{*}{ May } & $\mathrm{O}$ & 3 & 66.6 & 133.3 & 66.6 & 266.6 \\
\hline & I & 3 & 100 & 166.6 & 133.3 & 399.9 \\
\hline \multirow[t]{2}{*}{ June } & $\mathrm{O}$ & 3 & 400 & 233.3 & 133.3 & 766.6 \\
\hline & I & 3 & 266.6 & 400 & 266.6 & 933.3 \\
\hline \multirow[t]{2}{*}{ July } & $\mathrm{O}$ & 3 & 266.6 & 100 & 166.6 & 533.3 \\
\hline & I & 3 & 100 & 366.6 & 133.3 & 599.9 \\
\hline \multirow[t]{2}{*}{ August } & $\mathrm{O}$ & 3 & 233.3 & 66.6 & 200 & 499.9 \\
\hline & I & 3 & 100 & 333.3 & 166.6 & 599.9 \\
\hline \multirow[t]{2}{*}{ Sept. } & $\mathrm{O}$ & 3 & 200 & 33.3 & 166.6 & 399.9 \\
\hline & I & 3 & 66.6 & 266.6 & 200 & 533.3 \\
\hline \multirow[t]{2}{*}{ Oct. } & $\mathrm{O}$ & 3 & 200 & 66.6 & 133.3 & 399.9 \\
\hline & I & 3 & 100 & 266.6 & 166.6 & 533.3 \\
\hline \multirow[t]{2}{*}{ Nov. } & $\mathrm{O}$ & 3 & 133.3 & 66.6 & 100 & 299.9 \\
\hline & I & 3 & 33.3 & 166.6 & 133.3 & 333.3 \\
\hline \multirow[t]{2}{*}{ Dec. } & $\mathrm{O}$ & - & - & - & - & - \\
\hline & I & - & - & - & - & - \\
\hline \multirow[t]{2}{*}{ Jan. } & $\mathrm{O}$ & - & - & - & - & - \\
\hline & I & - & - & - & - & - \\
\hline \multirow[t]{2}{*}{ Feb. } & $\mathrm{O}$ & - & - & - & - & - \\
\hline & I & - & - & - & - & - \\
\hline \multirow[t]{2}{*}{ March } & $\mathrm{O}$ & 3 & 133.3 & 66.6 & 66.6 & 266.6 \\
\hline & I & 3 & 33.3 & 166.6 & 66.6 & 266.6 \\
\hline
\end{tabular}

Table 2. Average standardized individual numbers observed outside and inside of livestock enclosure area . $(*=\mathrm{p}<0.05 ; * *=\mathrm{p}$ $<0.01 ; * * *=\mathrm{p}<0.001)$.

\begin{tabular}{lllll}
\hline Species & Outside & Inside & $\mathrm{t}$ & $\mathrm{P}$ \\
\hline Urosaurus & 188.9 & 92.6 & 2.2 & $*$ \\
Uta & 92.6 & 251.8 & 4.1 & $* * *$ \\
Cnemidophor & 125.9 & 162.9 & 1.5 & $\mathrm{~ns}$ \\
Total & 407.4 & 507.3 & & \\
\hline
\end{tabular}

\section{DISCUSSION}

Individual abundance changes during the year could be explained both by changes in environmental factors and by reproductive cycles of the three species.
June is the month in which the rainy season began. Ortega \& Hernández (1983) have shown that the availability of lizard prey was correlated with the increase of precipitation. June is the month when the newborn individuals, which were born in May, were recruited by the older age class.

Ortega et al., (1989) have suggested that the strong preferences shown by lizard species to specific kinds of microhabitats was the result of responses evolved to cope with a complex combination of various selective pressures. Lizards depend strongly on close substrate adaptation to thermoregulate efficiently, to mate successfully, to defend territories, and to avoid predators. 
Table 3. Microhabitat characteristics inside and outside the exclusion area. $X^{2}(*=\mathrm{p}<0.05 ; * *=\mathrm{p}$ $<0.01 ; * * *=\mathrm{p}<0.001)$.

\begin{tabular}{lcccc}
\hline Characteristics & $\begin{array}{c}\text { Outsi } \\
\text { de }\end{array}$ & Inside & $X^{2}$ & $\mathrm{P}$ \\
\hline Exposed soil cover \% & 76 & 5 & 100 & $* *$ \\
& & & 8 ? & $*$ \\
Grass \& herb cover \% & 24 & 95 & 53. & $* * *$ \\
& & & 06 & $* *$ \\
Grass \& herb height cm & 4.22 & 24 & 16. & $* *$ \\
Stones cover $\%$ & 24 & 20 & 1.2 & $\mathrm{~N}$ \\
Fallen trunk cover \% & 6.2 & 2.9 & 3.9 & $*$ \\
& & & 86 & \\
\hline
\end{tabular}

\begin{tabular}{lccrr}
\hline Trees & & & & \\
& & & & \\
\hline Density & 44 & 80 & 16. & $* *$ \\
Species \% & 20.8 & 17.3 & 0.0 & N \\
Height & 2.15 & 2.7 & 0.1 & $\mathrm{~N}$ \\
& & & 12 & $\mathrm{~S}$ \\
Cover & 6.77 & 7.08 & 0.0 & $\mathrm{~N}$ \\
& & & 13 & $\mathrm{~S}$ \\
\hline Shrubs & & & & \\
\hline Density & 360 & 307 & 9.1 & $* *$ \\
Species \% & & & 49 & $*$ \\
Height & 41.6 & 58.6 & 2.2 & $\mathrm{~N}$ \\
Cover & 1.42 & 1.81 & 0.0 & $\mathrm{~N}$ \\
& & & 84 & $\mathrm{~S}$ \\
Cacti & 2.55 & 3.98 & 0.5 & $\mathrm{~N}$ \\
& & & 13 & $\mathrm{~S}$ \\
\hline Density & & & & \\
Species \% & 369 & 347 & 1.3 & $\mathrm{~N}$ \\
Height & & & 94 & $\mathrm{~S}$ \\
Cover & 29.2 & 20.7 & 3.4 & $* *$ \\
& & & 9 & $\mathrm{~N}$ \\
& 1.51 & 1.63 & 0.0 & $\mathrm{~N}$ \\
& & & 08 & $\mathrm{~S}$ \\
& 1.06 & 1.58 & 0.1 & $\mathrm{~N}$ \\
& & & 71 & $\mathrm{~S}$ \\
\hline
\end{tabular}

Jones (1981), in a study made in five different community types, demonstrated that grazing reduced overall lizard abundance and species diversity when associated with changes in structural composition.

Conversely, communities not affected structurally by grazing showed little or any difference in lizard abundance or diversity.

Although the vegetation at "El Comitan" study area showed differences in cover and density between the grazed and ungrazed, in our study site at both system transects the vegetation taxonomic composition was similar.
The results of this work for Urosaurus nigricaudus, which was more abundant in the grazed site, are in accordance with Vitt \& Ohmart (1974), who demonstrated a relationship between the number of downed limbs and branches of mesquite trees and the number of Sceloporus magister, Urosaurus ornatus, and Urosaurus graciosus populations. They found that adult $S$. magister used both trees and downed litter while juveniles primarily used downed litter.

They hypothesized that adults were able to forage on both large and small prey, but juveniles only on small prey. By using primarily downed litter, juvenile $S$. magister were able to reduce prey size competition with adults and $U$. ornatus and $U$. graciosus, all of which foraged on small prey items but spent a majority of their time in trees. Thus, the reduction in prey competition created by increased numbers of downed tree limbs at grazed sites might account for the greater abundance of $U$. nigricaudus found in the current study.

The greatest effect of grazing was on the abundance of the sit- and- wait type lizard species predating in soils, such as Uta stansburiana. Their lower abundance at grazing sites would seem to be related to losses in low vegetative cover, particularly perennial grass. Perennial grass tended to moderate conditions of surface and near surface microenvironmental regimes (increased water retention and cooler temperatures) (Jones, 1981). The lack of perennial grass at grazed sites created xeric microenvironmental conditions at or near the surface, resulting in unfavorable conditions for species that foraged over large areas, like Uta spp.

Losses in perennial grass reduced the abundance of certain invertebrate species and thus the food available to some species of lizards. This was particularly disadvantageous to lizards that spent a great deal of time and energy actively seeking prey (Vitt \& Ohmart, 1974; Tubbs, 1977).

Cnemidophorus hyperythrus was a widely foraging species and therefore was not affected by the changes in cover and density in herbs because it was in continuous movement. 
Data presented in this paper indicated that not all lizards were adversely affected by livestock grazing. Land management managed vegetation and not individual species. By understanding relationships between various foraging groups and vegetative structure, and how grazing affected such structures, grazing system and habitat management plans could be developed that would allow for the most diverse and abundant fauna in any given vegetative community.

\section{ACKNOWLEDGEMENTS}

This work was supported by the Centro de Investigaciones Biologicas del Noroeste, The Secretaría de Educación Pública, and the Consejo Nacional de Ciencia y Tecnología of México. We would like to thank M. Acevedo B, F. Cota, S. Arguelles M., R. Domínguez C., and P. Galina T., for their help during the field work. Thanks also to two anonymous reviewers who improved an early version of this manuscript and to Ellis Glazier, for editing the English language text, and Dolores Vázquez who typed the manuscript.

\section{RESUMO}

Os cambios na reproduo de 3 especies de lagartixas foram definidos e tem sido comparados em dois sitios de matos deserticos: um de pastoreado e o outro no, localizados nos arrededores Cidade de La Paz, na Regio del Cabo na Baja California Sur no Mexico, no lapso de abril de 1992 ao maro de 1993.

Foram desenvolvidos um total de 54 censos para as tres espcies com base ao sistema de " dois transectos"- quer dizer: um dentro e o outro fora da excluso de gado. O resultado foi: uma lagartixa foi negativamente afectada pelas actividades de pastoreo. Uma outra mostr um aparente efecto positivo pelas mesmas condies e a terceira, no mostro alterao nehuma pelo pastoreo. Este artgo pe em causa, as posiveis relaes entre a especificidade do microhabitat de cada uma das espcies e a sua resposta de abundncia no numero de indivduos.

\section{REFERENCES}

Alvarez, S., P. Galina \& Ortega-Rubio, A. (1989), Structure and composition of two lizard communities of the Cape Region, Baja California Sur, México. Bull. Maryland Herpetol. Soc., 25, 40-48

Anderson, J. E. \& Holte, R.E. (1981), Vegetation development over 25 years without grazing on sagebrush dominated rangeland in southeastern Idaho. J. Range Manag., 34, 25- 29

Bock, C. E., J. H. Bock, W. R. Kenney \& Hawthorne, V.M. (1984), Responses of birds, rodents, and vegetation to livestock exclosure in a semidesert grassland site. $J$. Range Manag., 37, 239-242

Bock, C. E., H. M. Smith \& J. H. Bock. (1990), The effect of livestock grazing upon abundance of the lizard Sceloporus scalaris, in southeastern Arizona. J. Herpetol., 24, $445-446$

Bury, R. B. \& Busack, S. D. (1974), Some effects of off-road vehicles and sheep grazing on lizard populations in Mohave Desert. Biol. Conservation. 6, 179-183

Chew, R. M. (1982), Changes in herbaceous and sufrutescent perennials in grazed desertified grassland in southeastern Arizona, 19581978. Amer. Midland Nat., 108, 159-169

García, E. (1973), Modificaciones al Sistema de Clasificación Climática de Koeppen. 2a. Ed. Instituto de Geografía. UNAM. México, D.F. pp 246

Heske, E. J. \& Campbell., M. C. (1991), Effects of an 11 year livestock exclosure on rodent and ant numbers in the Chihuahuan desert, Southeastern Arizona. Southwest. Nat,. 36, 89-93

Janzen, D. H. (1976), The depression of reptile biomass by large herbivores. Amer. Nat., 110, 371-400

Jones, K. B. (1981), Effects of grazing on lizard abundance and diversity in Western Arizona. Southwest. Nat., 26, 107-115

León De La Luz, J. L., Coria, R., Cruz, M. \& Domínguez, R. (1996), Patrones fenológicoreproductivos de una comunidad áridotropical en Baja California Sur. Acta Bot. Mex. 35,45-64 
Linsdale, J. M. (1946), The California ground squirrel. University California Press. Berkeley. pp. 475

Milchunas, D. G., Sala, O. E. \& Laureroth, W. K. (1988), A generalized model of the effects of grazing by large herbivores on grassland community structure. Amer. Nat., 132, 87-106

Moore, P. D. \& Chapman, S. B. (1986), Methods in Plant Ecology. Blackwell Scientific Publications. Oxford, pp. 275

Ortega-Rubio A., Alvarez-Cárdenas, S. \& Galina-Tessaro, P. (1989), Possible effects of microhabitat avaibility. on lizard diversity and density at Baja California Sur. Miscel. Zool., 13, 133-139

Ortega, R. A. \& Hernández., L. (1983), Abundancia relativa de insectos en un medio estacional: su influencia en la historia de vida de dos iguanidos simpatricos. Fol. Entomol. Mex., 55, 129-144

Reynolds, H. G. (1950), Relation of merriam kangaroo rats to range vegetation in southern Arizona. Ecology, 31, 456-463
Romero-Schmidt, H., Ortega-Rubio, A., Arguelles-Mendez, C., Coria-Benet, R. \& Solís-Marín, F. (1994), Effect of Livestock Grazing Exclosure upon abundance of lizard community in Baja California Sur, México. Bull. Chicago Herpetol. Soc., 29, 245-248

Tubbs, A. A. (1997), Effects of artificial crowding on behavior, growth and survival of juvenile spiny lizards. Copeia, 820-823

Vitt, L. J. \& Ohmart, R. D. (1974), Reproduction and ecology of a Colorado River population of Sceloporus magister. Herpetol., 30, 410-417

West, N. E., Provenza, F. D., Johnson, P. S. \& Owens, M. K. (1984), Vegetation changes after 13 years of livestock grazing exclusion on sagebrush semidesert in west central Utah. J. Range Manag., 37, 262-264 